\title{
Multiple pathogens found in growth-retarded black tiger shrimp Penaeus monodon cultivated in Thailand
}

\author{
Kanokporn Chayaburakul ${ }^{1}$, Gary Nash ${ }^{2}$, Phusit Pratanpipat ${ }^{3}$, Siriporn Sriurairatana ${ }^{2}$, \\ Boonsirm Withyachumnarnkul ${ }^{1,2, *}$
}

\author{
${ }^{1}$ Department of Anatomy, and ${ }^{2}$ Centex Shrimp Faculty of Science, Mahidol University, Rama 6 Road, Bangkok 10400, \\ Thailand
}

${ }^{3}$ Shrimp Culture Research Center, Charoen Pokphand Foods Public Company (Limited), Samut Sakhon 74000, Thailand

\begin{abstract}
In 2001-2002 throughout Thailand, black tiger shrimp Penaeus monodon farmers reported very unusual retarded growth. We have called this problem monodon slow growth syndrome (MSGS). Based on decreased national production, estimated losses due to this phenomenon were in the range of 13000 million baht (approximately US\$ 300 million) in 2002. Since rearing practices had not changed, it was considered possible that the MSGS problem may have arisen from a new or existing pathogen. To examine this possibility, cultivated shrimp were sampled from 32 commercial rearing ponds that reported abnormally slow growth from eastern, central and southern regions of Thailand. Shrimp were randomly sampled from each pond and grouped into normal and small shrimp. Normal shrimp were defined as those with body weights (BW) of $24 \mathrm{~g}$ or more while small shrimp were defined as those that weighed $16.8 \mathrm{~g}$ or less. Pleopods were used for detection of monodon baculovirus (MBV), heptopancreatic parvovirus (HPV) and infectious hypodermal and hematopoietic necrosis virus (IHHNV) using specific polymerase chain reaction (PCR) assays. In addition, some shrimp were processed for normal histopathology and transmission electron microscopy (TEM). Most of the shrimp specimens were infected by at least 1 of these viruses but many had dual or multiple infections. Prevalence of HPV and combined HPV/MBV infections in the small shrimp was significantly higher than in the normal shrimp. In addition to the viruses, a new microsporidian species, gregarines and bacteria were also observed but were not significantly associated with the MSGS problem. Some of the small shrimp gave negative results for all these pathogens by PCR and histology and no new and unique histopathology was recognized in any of the samples. The findings suggested that HPV infection was a contributing factor but not the overriding factor responsible for MSGS. It is possible that MSGS is caused by an unknown pathogen or by some other presently unknown, non-pathogenic factor.
\end{abstract}

KEY WORDS: Penaeus monodon · Growth retardation · MBV · HPV · IHHNV · Microsporidian · Gregarines

Resale or republication not permitted without written consent of the publisher

\section{INTRODUCTION}

Many Thai shrimp farmers share the general opinion that the growth of farmed Penaeus monodon has been severely retarded in all culture systems throughout Thailand since the second crop of 2001. We have called this problem monodon slow growth syndrome (MSGS).
Indeed, the production of farmed $P$. monodon in Thailand declined from 249633 metric tons (t) valued at 107890 million baht (ca. US\$ 2697 million) in 2000 and $255568 \mathrm{t}$ valued at 98680 million baht (ca. US\$ 2467 million) in 2001 to $212091 \mathrm{t}$ valued at 73847 million baht or US\$ 1846 million in 2002 (Customs Department, Thailand). Farmers claimed that most of this 
decline resulted from retarded growth. If even half of the decline could be attributed to retarded growth, it would have amounted to a production loss valued at approximately 13000 million baht (ca. US\$ 310 million) in 2002 alone.

Normally, farmed Penaeus monodon reach a size of 24 to $40 \mathrm{~g}$ after 4 mo of culture at a stocking density of 30 to 50 ind. $\mathrm{m}^{-2}$ and this translates into an average daily weight gain (ADG) of 0.2 to $0.3 \mathrm{~g} \mathrm{~d}^{-1}$ over the whole culture period. Growth rates much lower than this can lead to unprofitable crops in the normal Thai, semi-intensive cultivation system and may result in bankruptcy if such crops follow in succession. In the problematic interval 2001-2002, farmers reported ADG in the range of 0.07 to $0.15 \mathrm{~g} \mathrm{~d}^{-1}$. During that interval, there were no substantial changes in broodstock sourcing, hatchery practice or cultivation practice, nor were there exceptional weather patterns when compared to previous years. Environmental factors (water quality, salinity, etc.) and farm practices can contribute to slow growth, but it seems unlikely that substantial changes in these factors would have been sufficiently uniform or that they acted uniformly in concert to result in a country-wide phenomenon affecting ponds operating over a wide salinity range. Rather, the nature of the phenomenon suggests that a common underlying factor might have been the cause.

Since the slow growth problem with Penaeus monodon has continued into 2003, increasing numbers of shrimp farmers have turned to cultivation of imported stocks of $P$. vannamei (also called Litopenaeus vannamei). This is because they have found that the imported stocks grow well in the former P. monodon ponds using essentially unchanged cultivation practices. In other words, they suffer no growth retardation. Despite the success with $P$. vannamei, Thai farmers prefer to rear P. monodon, since it grows to larger sizes that generally fetch higher prices. However, a return to P. monodon cultivation necessitates solving the MSGS problem. The problem may have arisen from a common factor related to the $P$. monodon postlarvae used to stock the ponds. One possible underlying factor could be a widespread increase in the prevalence of an existing or new pathogen in the cultivation system. To assess whether any recognizable pathogen was consistently associated with MSGS in P. monodon in Thailand, we examined a large sample of normal size and abnormally small shrimp from 32 MSGS culture ponds in 3 cultivation regions in Thailand in 2002.

\section{MATERIALS AND METHODS}

Thirty-two MSGS Penaeus monodon culture ponds located in eastern, central and southern Thailand were included in this study. Salinity in the ponds ranged from 30 to 0 ppt. The latter comprised ponds where cultivation at stocking began at approximately $10 \mathrm{ppt}$ and was followed by gradual addition of fresh water until readings with a standard refractometer registered 0 ppt. The pond size varied from 4 to 6 rai ( 0.7 to 0.9 ha) and the stocking density varied from 30 to 45 postlarvae $15\left(\mathrm{PL}_{15}\right) \mathrm{m}^{-2}$.

At harvest (approximately after 4 mo of culture), ADG, average body weight (ABW) and coefficient of variation for $A B W$ were recorded. At the same time, 10 normal shrimp and 10 small shrimp from each of the 32 ponds were tested for the presence of monodon baculovirus (MBV), heptopancreatic parvovirus (HPV), infectious hypodermal and hematopoietic necrosis virus (IHHNV) and white spot syndrome virus (WSSV) by single-step PCR assay and for yellow head virus (YHV) by single-step RT-PCR. Normal shrimp were defined as shrimp that had body weights (BW) of $24 \mathrm{~g}$ or more (i.e. ADG of $0.2 \mathrm{~g} \mathrm{~d}^{-1}$ or higher) while small shrimp were defined as those that weighed $16.8 \mathrm{~g}$ or less (i.e. at least $70 \%$ lower BW than normal shrimp and ADG $0.14 \mathrm{~g} \mathrm{~d}^{-1}$ or less). PCR assay for MBV followed the protocol described by Belcher \& Young (1998), HPV the protocol described by Phromjai et al. (2002) and IHHNV the protocol described in the OIE manual (Office International des Epizooties 2000). WSSV assays were performed using an Ezee-Gene detection kit purchased from the Shrimp Biotechnology Business Unit (Thai National Center for Genetic Engineering and Biotechnology). YHV RT-PCR followed the protocol described by Wongteerasupaya et al. (1997). Template DNA was prepared from the juvenile shrimp by removal of pleopods on the last abdominal segment followed by extraction using a commercial kit (Qiagen). The optical density of the DNA extracts was measured and adjusted so that the total DNA template for each PCR reaction was $150 \mathrm{ng} \mathrm{ul}^{-1}$. After PCR, $10 \mu$ l of the reaction mixture was subjected to electrophoresis on $1.5 \%$ agarose gels followed by ethidium bromide staining and visualization by a UV transilluminator. PCR product band intensity (0 to 4 ) was used as a crude measure of infection severity with 0 = no visible band, 1 = faintly visible band, 2 = light band, 3 = thin, intense band and $4=$ thick, intense band. These values were used for calculation of mean severity indices for each disease in the large and small shrimp from each pond.

Estimated prevalence of individual pathogens was calculated by using the software program Survey Toolbox for Aquatic Animal Diseases (Cameron 2002), with sensitivity set at $95 \%$, specificity set at $99 \%$ and population size set at 100000 . The sensitivity setting meant that for every 100 diseased shrimp tested, 95 were expected to give a true positive result while 5 were 
expected to give a false negative result. The specificity meant that for every 100 disease-free shrimp, 1 was expected to give a false positive result. To estimate the prevalence of test-negative shrimp in any pond, the total number of infected shrimp was estimated as described above and subtracted from $100 \%$. All values of estimated prevalence were expressed as means \pm SD. Statistical analysis was performed using SPSS program software version 9 .

In addition to the shrimp sampled for PCR analysis, 5 to 10 shrimp each of large and small sizes were sampled at harvest from each pond and examined by light microscopy (LM). A few samples were taken for transmission electron microscopy (TEM) to confirm diagnoses by LM. The total number of shrimp examined by LM was 159. They were processed for normal histology and H\&E staining as described by Lightner (1996) and examined by LM for the presence of known viral, bacterial and parasitic infections and for other abnormalities. Severity was graded as 0 for no infection, 1 for slight severity affecting less than $1 / 3$ of the tissue or organ, 2 for moderate severity affecting $2 / 3$ of the tissue or organ, and 3 for marked severity affecting greater than $2 / 3$ of the tissue/organ.

From a few ponds where a previously unreported protozoan infection had occurred in the hepatopancreas additional specimens were prepared. Samples of the hepatopancreas were removed aseptically from living shrimp and divided into 2 portions. One portion was used to prepare fresh smears for H\&E staining while the other portion was fixed and processed for examination by TEM. The smears were made by first placing a drop of $2.8 \% \mathrm{NaCl}$ solution containing $6 \%$ formalin fixative on a microscope slide. The hepatopancreas was clipped with sterile scissors, held with a pair of forceps and the cut side was placed in the drop of fixative before smearing. After drying, the slide was processed for H\&E staining as described by Lightner (1996).

For TEM, ice-cold fixative containing $6 \%$ glutaraldehyde in phosphate buffer (Lightner 1996) was injected directly into the hepatopancreas followed by cutting into small pieces $\left(\sim 1 \mathrm{~mm}^{3}\right)$. The samples were stored in the same fixative for $6 \mathrm{~h}$ at $4^{\circ} \mathrm{C}$ before transfer to ice-cold phosphate buffer and post fixation with $1 \%$ osmium tetroxide at room temperature (RT, approximately $25^{\circ} \mathrm{C}$ ) for $1 \mathrm{~h}$. The specimens were then dehydrated at RT in a graded series of ethanol (15 min each in $30,50,70,80$, and $95 \%$, and twice in absolute ethanol). This was followed by 2 changes of propylene oxide (PO) for $30 \mathrm{~min}$ each before transfer to a mixture of PO and Araldite at a ratio of 3:1 for $1 \mathrm{~h}$ followed by a mixture of PO and Araldite at a ratio of 2:1 for $2 \mathrm{~h}$. They were then transferred to a mixture of PO and Araldite at a ratio of 1:2 and held overnight in closed tubes. The

tubes were opened for $6 \mathrm{~h}$ and the samples were transferred to flat molds for $24 \mathrm{~h}$ at RT before polymerization for $2 \mathrm{~d}$ each at 45 and $60^{\circ} \mathrm{C}$. Semi-thin sections (1 $\mu \mathrm{m}$ thick) were placed on a drop of double-distilled water on a regular microscope glass slide and heated at $40^{\circ} \mathrm{C}$ for 1 to $2 \mathrm{~min}$, stained with $1 \%$ toluidine blue in $1 \%$ sodium borate at $60^{\circ} \mathrm{C}$ for $1 \mathrm{~min}$ and then observed by LM for the presence of protozoan spores. Two to three consecutive ultra-thin sections from these blocks were placed on 200 mesh copper grids and stained with $2 \%$ uranyl acetate and lead citrate for examination using a Hitachi H7500 TEM.

\section{RESULTS}

\section{Growth rate}

From the 32 commercial shrimp ponds examined, the abnormally low average BW was $12.5 \mathrm{~g}$ (Table 1 ) instead of the expected minimum of $24 \mathrm{~g}$. This translated into a non-profitable ADG of $0.11 \mathrm{~g} \mathrm{~d}^{-1}$ for the 4 mo cultivation period. The average coefficient of variation $(\mathrm{CV})$ for body weight was $66 \%$ instead of the normally expected 15 to $20 \%$ (Charoen Phokphand feed company standard). These were considered to be ponds exhibiting MSGS.

\section{Pathogen survey by PCR assay}

PCR assays for WSSV and RT-PCR assays for YHV were negative for all MSGS pond specimens tested. By contrast, many positives were found for MBV, HPV and IHHNV by PCR assay (Table 2) but none of these individual viruses were found in all of the 32 MSGS ponds. MBV-positive ponds (29/32 or $91 \%)$ were most common at single $(3 \%)$, dual $(50 \%)$ and triple $(38 \%)$ virus positive status. The next most frequently encountered virus was HPV but only in dual (34\%) and triple virus positive ponds. No pond was positive for HPV alone.

Table 1. Data from 32 Thai commercial shrimp ponds reporting monodon slow growth syndrome (MSGS) over approximately 4 mo during the second crop of 2002 (harvested June-August). Data are means \pm SD for culture period and salinity while shrimp parameters are means \pm SE of individual pond averages for body weight, average daily growth and coefficients of variation

Culture period $(\mathrm{d})$

Water salinity (ppt)

Average body weight ( $g$ )

Average daily growth $\left(\mathrm{g} \mathrm{d}^{-1}\right)$

Coefficient of variation of body weights (\%)
$118 \pm 13$

$11 \pm 8$

$12.5 \pm 3.4$

$0.11 \pm 0.03$

$66 \pm 39$ 
Table 2. Number and percent of surveyed ponds showing the presence of 1 or more of the 3 viruses monodon baculovirus (MBV), heptopancreatic parvovirus (HPV) and infectious hypodermal and hematopoietic necrosis virus (IHHNV) by PCR assay

\begin{tabular}{|lcc|}
\hline Pathogen or combination & \# ponds positive & \% total (32) \\
\hline None & 1 & 3 \\
MBV only & 1 & 3 \\
HPV only & 0 & 0 \\
IHHNV only & 2 & 6 \\
MBV/HPV only & 11 & 34 \\
MBV/IHHNV only & 5 & 16 \\
HPV/IHHNV only & 0 & 0 \\
HPV/MBV/IHHNV & 12 & 38 \\
Total & $\mathbf{3 2}$ & $\mathbf{1 0 0}$ \\
Any viruses & 31 & 97 \\
Any MBV & 29 & 91 \\
Any HPV & 23 & 72 \\
Any IHHNV & 19 & 59 \\
Any MBV+HPV & 23 & 72 \\
Any MBV+IHHNV & 17 & 53 \\
Dual infections & 16 & 50 \\
Dual to triple infections & 28 & 88 \\
\hline
\end{tabular}

IHHNV was the least frequently encountered (19/32 ponds or $59 \%)$ as single $(6 \%)$, dual $(16 \%)$ and triple virus positive ponds. Dual positives of any viral combination occurred in $50 \%$ of the ponds and dual to triple positives in $88 \%$ of the ponds. One MSGS pond $(1 / 32$ or $3 \%$ ) gave negative tests for all of the viruses tested.

\section{Estimated pathogen prevalence in small and large shrimp}

Using the number of shrimp tested and found positive in PCR assays, survey software estimates of mean prevalence were calculated for HPV and combined HPV/MBV infections and these were found to be significantly $(\mathrm{p} \leq 0.05)$ higher in the small size shrimp population than in the normal size shrimp population (Table 3). Although the estimated prevalence of MBV and IHHNV was high, it was not significantly different in the normal and small size shrimp populations.

\section{Histological analysis}

LM of H\&E stained tissues of the shrimp at harvest revealed the presence of pathognomonic lesions for MBV and HPV (Lightner 1996) and confirmed the PCR assay results. LM also revealed the presence of bacterial lesions and gregarines (Lightner 1996) and a previously undescribed sporulating protozoan parasite that was not covered by the PCR assays (Table 4). Stages of the protozoan were detected in the hepatopancreas, and gregarines were detected in the midgut lumen. Bacter-
Table 3. Estimated mean pond prevalence $( \pm \mathrm{SD})$ of pathogens in normal and small size shrimp Penaeus monodon populations calculated from results of PCR analysis of 10 normal and 10 small shrimp randomly sampled after approximately 4 mo of cultivation in 32 commercial shrimp ponds reporting abnormally slow growth. ${ }^{*}$ Significant differences at $\mathrm{p}<0.05$

\begin{tabular}{|lcr|}
\hline Pathogen & $\begin{array}{c}\text { Normal size } \\
\text { shrimp }\end{array}$ & $\begin{array}{c}\text { Small size } \\
\text { shrimp }\end{array}$ \\
\hline MBV only & $81 \pm 27$ & $87 \pm 26$ \\
HPV only* & $65 \pm 4$ & $74 \pm 32$ \\
IHHNV only & $45 \pm 26$ & $47 \pm 25$ \\
Combined HPV/MBV* & $61 \pm 32$ & $67 \pm 33$ \\
Combined HPV/IHHNV & $37 \pm 19$ & $39 \pm 21$ \\
Combined MBV/IHHNV & $40 \pm 25$ & $41 \pm 24$ \\
Combined HPV/MBV/IHHNV & $35 \pm 18$ & $36 \pm 18$ \\
Negative for tested pathogens & $15 \pm 26$ & $8 \pm 22$ \\
\hline
\end{tabular}

ial infections present as hemocytic enteritis and septic hepatopancreatitis were observed in $6 \%$ of the normal shrimp and $9 \%$ of the small shrimp. Bacteria were often concurrent with other pathogens as dual or multiple infections. Prevalence of pathogens in the normal and small shrimp was comparable. Although IHHNV infection had been detected by $\mathrm{PCR}$, no pathognomonic Cowdry A type-inclusions typical of IHHNV infection (Bell \& Lightner 1984) were detected by histology.

Table 4. Percentage of samples showing various pathogens as detected by histopathology in 71 normal and 88 small shrimp sampled from 32 MSGS ponds

\begin{tabular}{|lcc|}
\hline Pathogen & $\begin{array}{c}\text { \% of normal } \\
\text { size shrimp }\end{array}$ & $\begin{array}{c}\text { \% of small } \\
\text { size shrimp }\end{array}$ \\
\hline Single infections & 58 & 52 \\
MBV & 38 & 30 \\
Microsporidian & 13 & 6 \\
Gregarine & 1 & 5 \\
HPV & 0 & 2 \\
Bacteria & 6 & 9 \\
Dual infections & 15 & 26 \\
MBV/HPV & 7 & 10 \\
MBV/Microsporidian & 7 & 6 \\
MBV/Gregarine & 1 & 6 \\
HPV/Microsporidian & 0 & 2 \\
Microsporidian/Gregarine & 0 & 2 \\
Triple infections & 9 & 7 \\
MBV/HPV/Microsporidian & 7 & 5 \\
MBV/HPV/Gregarine & 1 & 1 \\
MBV /Microsporidian/Gregarine & 1 & 1 \\
Quadruple infections & 1 & 1 \\
Any of the tested pathogens & 83 & 86 \\
None of the tested pathogens & 17 & 15 \\
Dual to quadruple infections & 31 & 39 \\
Overall prevalence for each pathogen & \\
MBV & 63 & 60 \\
Microsproidians & 29 & 23 \\
HPV & 16 & 21 \\
Gregarines & 5 & 16 \\
& & \\
\hline
\end{tabular}


About $17 \%$ of the normal and $15 \%$ of the small size shrimp samples were histologically negative for pathogens observed in the other specimens (Table 3). These 'non-infected' shrimp comprised the 4th largest group after the HPV infection group.

Histologically, infections by the microsporidian not previously reported from Thailand comprised the second largest infection group after the MBV infection group (Table 3). It was first noted histologically in cultured Penaeus monodon and P. vannamei in September 2001 from 1 farm in the Gulf of Thailand and first considered to resemble a haplosporidian (Dykova et al. 1988). However, examination by TEM (see below) revealed that it was a microsporidian (Lightner 1996). By LM, histopathological changes caused by microsporidian infection included epithelial cell necrosis, sloughing and interstitial hemocytic infiltration of the hepatopancreas (Fig. 1a). At the early stage of infection while normal amounts of R-cell lipid were present, slight to moderate multifocal tubular epithelial cell necrosis, increased cytoplasmic basophilia, decreased cytoplasmic lipid, nuclear pyknosis and karyorrhexis were often observed. Cell necrosis was evidenced by cell shrinkage and rounding up within a vacuole leaving the cell surrounded by a clear halo. In moderately heavy infections, decreased hepatopancreatic R-cell lipid was evident with more prominent B-cells and tubular atrophy accompanied by many uni- and/or multinucleate protozoan stages that were intracytoplasmic or free in the tubular lumen together with numerous necrotic, sloughed tubular epithelial cells. Some of the sloughed cells were enlarged by masses of cytoplasmic spores.

Developing sporocysts were observed in smears of hepatopancreatic tissue of the infected shrimp by LM (Fig. 1c) and in thin tissue sections by TEM (Fig. 1d). TEM of mature spores (Fig. 1e,f) revealed a typical microsporidian polar filament within a polar tube, making 5 turns in 2 layers (Fig. 1e) and a polaroplast composed of compressed and vesiculated portions (Fig. 1f) (Hudson et al. 2001). The mature spores observed were ovoid to pyriform in shape and unusually small $(1.48 \times 0.82 \mu \mathrm{m})$.

\section{Severity comparisons}

Statistical comparison of mean severity values for large and small shrimp populations based on PCR data showed no significant differences for any of the viruses tested (Table 5).

When the PCR mean severity data for large and small shrimp pairs from all ponds were compared by Pearson Correlation Analysis, there was a positive correlation $(p \ll 0.01)$ between mean severity for large
Table 5. Mean severity comparisons for large and small shrimp based on PCR results. No significant differences were found between the large and small shrimp $(p>0.05)$

\begin{tabular}{|lcc|}
\hline Virus & $\begin{array}{c}\text { Large shrimp } \\
\text { mean severity }\end{array}$ & $\begin{array}{c}\text { Small shrimp } \\
\text { mean severity }\end{array}$ \\
\hline MBV & $1.5 \pm 2.2$ & $0.8 \pm 2.7$ \\
HPV & $3.6 \pm 1.5$ & $3.8 \pm 1.9$ \\
IHHNV & $0.6 \pm 0.4$ & $0.4 \pm 0.4$ \\
\hline
\end{tabular}

and small shrimp for all 3 viruses (i.e. correlation coefficients were 0.87 for $\mathrm{HPV}, 0.71$ for $\mathrm{MBV}$ and 0.67 for IHHNV). A comparison of the pooled data for all 3 viruses gave a positive correlation $(\mathrm{p} \ll 0.01)$ with a correlation coefficient of 0.85 . Preparation of an additive cumulative severity index (addition of 3 indices) for all 3 viruses resulted in a positive correlation ( $p \ll$ 0.01) with a correlation coefficient of 0.89 (Fig. 2). In summary, results from the mean severity comparison for large and small shrimp and from the correlation analysis were in agreement.

\section{DISCUSSION}

We found a high prevalence of multiple infections comprising several viruses, bacteria and protozoa in harvested shrimp from the 32 MSGS ponds surveyed. This phenomenon had been reported to be fairly common in grossly normal, farmed Penaeus monodon at harvest (Flegel 2001, Flegel et al. in press) before the advent of the nation-wide MSGS crisis. MBV was the most prevalent virus in the surveyed ponds in single to triple infections. However, this has long been the case and it is normally associated with stunting only late in pond culture (Flegel et al. 1999, in press). It had been common in Thailand long before the MSGS crisis, without being associated with striking effects on harvest weight (Fegan et al. 1991). It simply extended the grow-out period required by 1 or 2 wk to obtain large shrimp sizes (i.e. 25 to 33 shrimp $\mathrm{kg}^{-1}$ ).

HPV infections alone or in combination with MBV have been reported to be associated with much reduced growth rates (Flegel et al. 1999) that cannot be made up by extending the grow-out period. Although no pond was found to be infected with HPV alone, the number concurrently infected with MBV and HPV in dual to multiple infections was relatively high. In addition, the estimated prevalence of HPV was significantly higher in small shrimp than in normal shrimp. As stated earlier (Flegel et al. 1999), proof of a causal relationship between HPV and slow growth must await controlled challenge trials and these may now be possible since laboratory transmission of HPV has 


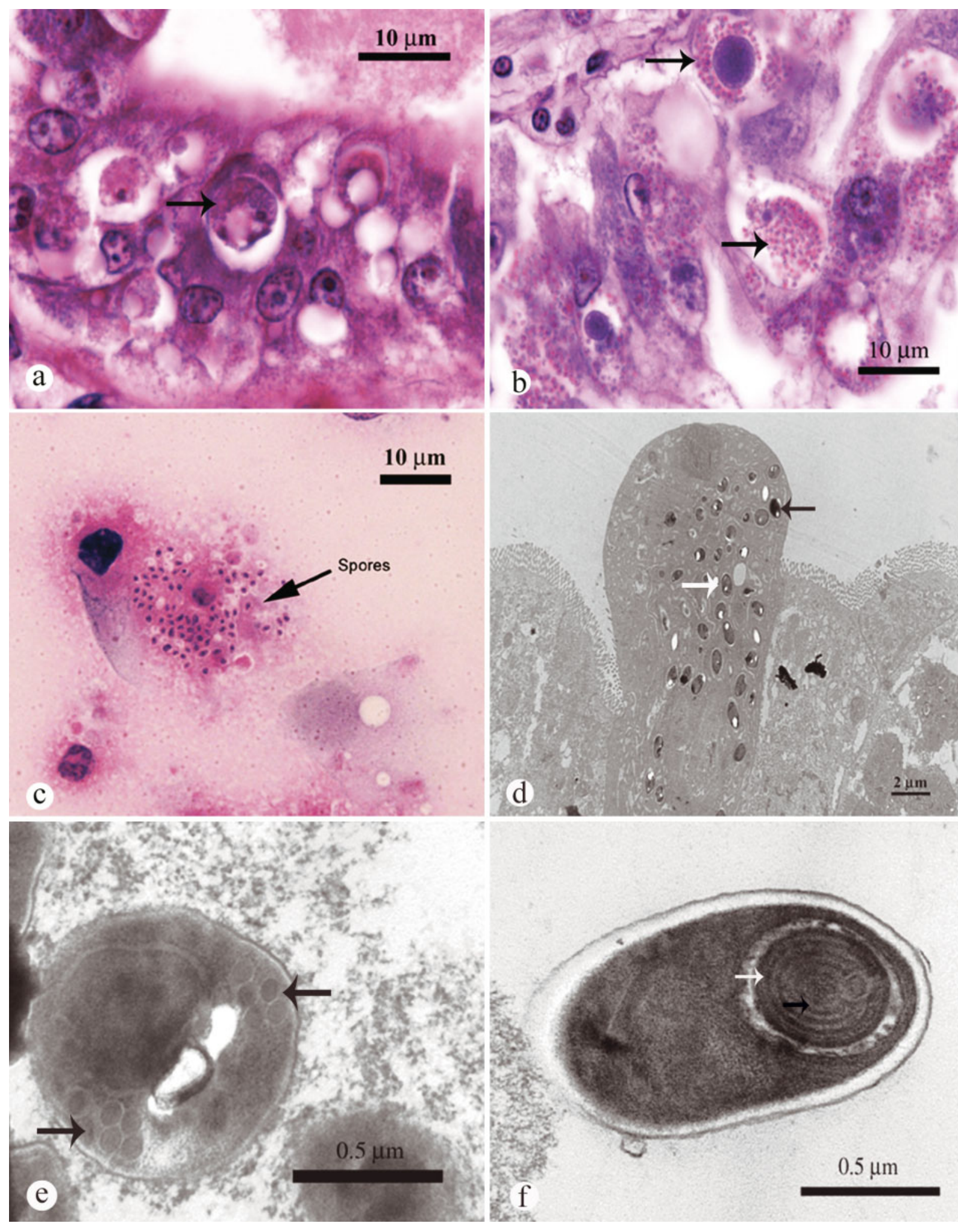

Fig. 1. Hepatopancreatic microsporidian by light microscopy. (a) Infection showing slight to moderate multifocal tubular epithelial cell necrosis (arrow); (b) late stage of infection showing numerous cytoplasmic spores and a number of multinucleated plasmodia (arrows); (c) spores in a fresh squash mount of infected hepatopancreatic tissue (arrow); (d) TEM of a thin section of hepatopancreatic tissue showing a cell containing mature (black arrow) and immature (white arrow) spores; (e) spore showing a polar filament (arrows) making 5 turns in 2 layers; (f) spore $(1.48 \times 0.82 \mathrm{~mm})$ showing compressed portion of the polaroplast. Black arrow points to electron-dense line; white arrow points to space between the 2 dense lines 


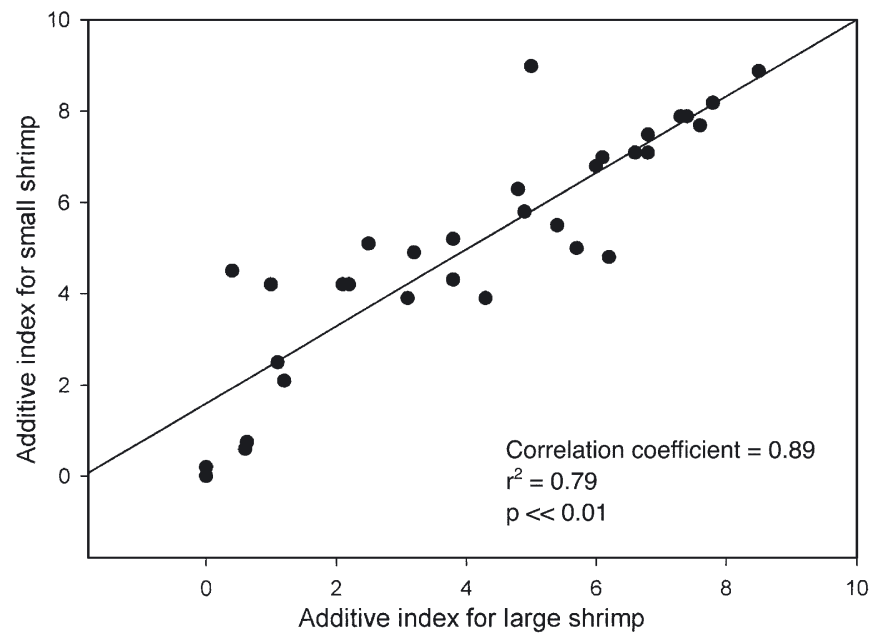

Fig. 2. Pearson correlation of additive mean severity indices for the large and small shrimp from each of the 32 ponds in the study. There was a strong $(p \ll 0.01)$ positive correlation (correlation coefficient 0.89 ) between severity index for the large and small shrimp from the same pond. Similar curves were also obtained for all of the viruses individually

recently been achieved (Catap et al. 2003). It is clear that slow growth was correlated with the presence of HPV in some of the ponds in the study. However, it was not found in all MSGS ponds, and HPV had been present in Thailand for many years prior to the MSGS crisis that began in late 2001. HPV was present only in combination with other viruses in $23(72 \%)$ of the 32 MSGS ponds. This suggested that there must be another cause(s) for the phenomenon in addition to or independent of HPV.

IHHNV has previously been shown to be relatively innocuous for pond-reared shrimp in Thailand, in spite of the fact that prevalence and severity may be high (Flegel et al. in press). The frequency of occurrence in MSGS ponds (59\%) also suggested that it was an unlikely candidate for causing the syndrome. Also, microsporidians, gregarines and bacteria were encountered too infrequently in the sampled shrimp to be likely causes. Finally, the fact that a reasonably large fraction of the small shrimp examined (15 to 20\%) were negative for the pathogens screened by PCR and histology supported the contention that some other unknown factor might be responsible for MSGS in these ponds.

One strong argument in favor of an unknown factor was the fact that the additive severity index for MBV, HPV and IHHNV for small and large shrimp in the same pond showed a very significant positive correlation. This suggested that the MSGS problem in the ponds was independent of whether infections of the 3 viruses were heavy or light and that some other overriding factor was responsible.
In addition to disease, environmental factors (water quality, salinity, etc.) and farm practices may also contribute to slow growth. However, it seems unlikely that substantial changes in these factors would have been sufficiently uniform or that they acted in concert throughout the country and in areas with different water quality. It is also unlikely that all Thai farmers would have made uniform mistakes in culture methods. There is also no indication that there was any uniform, countrywide change in hatchery operator practice during the interval. In addition, the successful rearing of Penaeus vannamei without growth problems in the same range of ponds using unchanged practices suggests that the problem is specific to P. monodon.

The possibility that captured broodstock used for larval production could have undergone uniform genetic changes leading to retarded growth or higher susceptibility to various pathogens is also unlikely. The MSGS crisis arose rather suddenly while genetic deterioration like inbreeding depression, for example, is a gradual process. Uniform genetic change is unlikely to have occurred in the natural shrimp populations sourced for broodstock over a wide area. Indeed, recent population studies on $P$. monodon broodstock from the Andaman Sea and the Gulf of Thailand have revealed high genetic diversity (Tassanakajon et al. 1998).

Of the 3 genera of Microsporidia (Agmasoma, Pleistophora and Ameson) reported in penaeid shrimp (Anderson et al. 1989, Lightner 1996) only Agmasoma penaei is fairly common in wild Thai shrimp, producing opaque white patches in infected shrimp tissues leading to the common names 'white back shrimp', 'milk shrimp', 'cotton shrimp' or 'roe shrimp' (Lightner 1988, Flegel et al. 1992, Pasharawipas et al. 1994, 1997). However, the new microsporidian described in this study was not $A$. penaei because it occurred in the hepatopancreatic tubule epithelium only and had much smaller spores. Although it is new to Thailand and although it does not correspond to any of the microsporideans described by Lightner (1996), further TEM work is needed to characterize it and determine whether or not it has been previously described. Since this new pathogen was equally prevalent in large and small shrimp and not in every MSGS pond, it was also unlikely to be the cause of MSGS.

In conclusion, the cause of MSGS in the past 2 years (2001-2002) in Thailand is not likely to have resulted from infections by the previously known pathogens MBV, HPV, IHHNV, gregarines and bacteria or by the new microsporidian, all of which cause lesions recognizable by LM. It is also unlikely that the problem arose from uniform environmental changes, uniform changes in husbandry practice or uniform genetic 
changes in Penaeus monodon stocks. We believe that an unknown pathogen(s) that does not produce recognizable lesions is the most likely underlying cause, although a non-pathogenic factor cannot yet be ruled out. If it is a pathogen, then more sophisticated techniques such as TEM or bioassays may be needed to detect it. For example, a cryptic mycoplasma and a parvovirus were reported from $P$. monodon in Australia (Ghadersohi \& Owens 1998, Owens et al. 1998). They do not cause high mortality, often produce no visible lesions and are most easily detected using molecular techniques. We must also include in the possibilities genetic variants of known viruses that have changed sufficiently to give negative results with the standard PCR and RT-PCR assays used. For working convenience, we have tentatively called the purported pathogen monodon slow growth agent (MSGA).

Acknowledgements. This study was funded by a Golden Jubilee Grant No. 4.A.MU/43/I.1, from the Thailand Research Fund (TRF), and also by the Mahidol University Grant from the 2002 budget. The authors would like to thank Miss Somjai Apisawetakan for TEM and Mr. Attaphon Satidkanitkul for assistance in preparing TEM photomicrographs. The authors would also like to thank Prof. D. V. Lightner, Aquaculture Pathology Section, Department of Veterinary Science and Microbiology, University of Arizona, Tucson, for assistance in interpreting the microsporidian histology.

\section{LITERATURE CITED}

Anderson IG, Shariff M, Nash G (1989) A hepatopancreatic microsporidian in pond-reared tiger shrimp, Penaeus mondon, from Malaysia. J Invertebr Pathol 53:278-280

Belcher CR, Yong PR (1998) Colorimetric PCR-based detection of monodon baculovirus in whole Penaeus monodon postlarvae. J Virol Methods 74:21-29

Bell TA, Lightner DV (1984) IHHN virus: infectivity and pathogenicity studies in Penaeus stylirostris and Penaeus vannamei. Aquaculture 38:185-194

Cameron A (2002) Survey toolbox for aquatic animal diseases. A practical manual and software package. ACIAR Monograph No. 94. Australian Centre for International Agricultural Research (ACIAR), Canberra

Catap ES, Lavilla-Pitogo CR, Maeno Y, Traviña RD (2003) Occurrence, histopathology and experimental transmission of hepatopancreatic parovirus infection in Penaeus monodon postlarvae. Dis Aquat Org 57:11-17

Dykova I, Lom J (1988) A new haplosporean infecting the hepatopancreas in the penaeid shrimp, Penaeus vannamei. J Fish Dis 11:15-22

Fegan DF, Flegel TW, Sriurairatana S, Waiakrutra M (1991) The occurrence, development and histopathology of monodon baculovirus in Penaeus monodon in Southern Thailand. Aquaculture 96:205-217

Flegel TW (2001) The shrimp response to viral pathogens. In: Browdy CL, Jory DE (eds) The new wave. Proceedings of the special session on sustainable shrimp aquaculture,

Editorial responsibility: Timothy Flegel,

Bangkok, Thailand
World Aquaculture 2001, Orlando. World Aquaculture Society, Boca Raton, FL, p 190-214

Flegel TW, Boonyaratpalin S, Fegan DF, Guerin M, Sriurairatana S (1992) High mortality of black tiger prawns from cotton shrimp disease in Thailand. In: Shariff $M$, Subasinghe RP, Arthur JR (eds) Disease in Asian aquaculture 1. Fish Health Section, Asian Fisheries Society, Manila, p 181-197

Flegel TW, Thamavit V, Pasharawipas T, Alday-Sanz V (1999) Statistical correlation between severity of hepatopancreatic parvovirus infection and stunting of farmed black tiger shrimp (Penaeus monodon). Aquaculture 174: 197-206

Flegel TW, Nielsen L, Thamavit V, Kongtim S, Pasharawipas $\mathrm{T}$ (in press) Presence of multiple viruses in non-diseased, cultivated shrimp at harvest. Agriculture

Ghadersohi A, Owens L (1998) Isolation, characterisation and DNA analysis of Mycoplasma spp. from moribund prawns Penaeus monodon cultured in Australia. Dis Aquat Org 35:53-61

Hudson DA, Hudson NB, Pyecroft S (2001) Mortalities of Penaeus japonicus prawns associated with microsporidean infection. Aust Vet J 79:504-505

Lightner DV (1988) Cotton shrimp disease. In: Sindermann CJ, Lightner DV (eds) Disease diagnosis and control in North American marine aquaculture. Elsevier, New York, p 70-75

Lightner DV (1996) A handbook of pathology and diagnotic procedures for diseases of penaeid shrimp. World Aquaculture Society, Baton Rouge, LA

Office International des Epizooties (OIE) (2000) Infectious hypodermal and hematopoietic necrosis and runt deformity syndrome (systemic agent: IHHNV), Chap 4.2.3. In: Diagnostic manual for aquatic animal diseases, 3rd edn. OIE, Paris, p 214-226

Owens L, Haqshenas G, McElnea C, Coelen R (1998) Putative spawner-isolated mortality virus associated with mid-crop mortality syndrome in farmed Penaeus monodon from northern Australia. Dis Aquat Org 34:177-185

Pasharawipas T, Flegel TW, Shaiyaroj S, Mongkolsuk S, Sirisinha S (1994) Comparison of amplified RNA gene sequences for microsporidian parasites (Agmasoma or Thelohania) in Penaeus merguiensis and P. monodon. Asian Fish Sci 7:169-178

Pasharawipas T, Sriurairatana S, Flegel TW, Thammavit $\mathrm{V}$ (1997) Use of DNA in situ hybridization, dot blot hybridization and PCR amplification to study a microsporidian parasite of penaeid shrimp. In: Flegel TW, MacRae IH (eds) Diseases in Asian aquaculture III. Fish Health Section, Asian Fisheries Society, Manila, p 317-323

Phromjai J, Boonsaeng V, Withyachumnarnkul B, Flegel TW (2002) Detection of hepatopancreatic parvovirus in Thai shrimp Penaeus monodon by in situ hybridization, dot blot hybridization and PCR amplification. Dis Aquat Org 51: $227-232$

Tassanakajon A, Pongsomboon S, Jarayabhand P, Klinbunga S, Boonsaeng V (1998) Genetic structure in wild populations of tiger shrimp (Penaeus monodon) using randomly amplified polymorphic DNA analysis. J Mar Biotechnol 6:249-254

Wongteerasupaya C, Boonsaeng V, Panyim S, Tassanakajon, Withyachumanarnkul B, Flegel TW (1997) Detection of yellow-head virus (YHV) of Penaeus monodon by RT-PCR amplification. Dis Aquat Org 31:181-186

Submitted: February 9, 2004; Accepted: March 25, 2004

Proofs received from author(s): July 7, 2004 